\title{
BRITAIN, THE TWO WORLD WARS, AND THE PROBLEM OF NARRATIVE*
}

\author{
DAVID REYNOLDS \\ Christ's College, Cambridge
}

A B S T R ACT. The concept of coming to terms with the past originated in post-I945 West Germany but such historical therapy is evident in all the belligerent countries. In that process, the two world wars are intricately connected, each seen refractively through the prism of the other. This article focuses on Britain whose national obsession with the two world wars is particularly acute. The first and second sections suggest that British public discourse has been able to construct a satisfying narrative of I939-45 but not of I9I4-18, meaning a narrative that has both a clear beginning, middle, and end and also a stark moral meaning. Viable narratives draw on the events themselves, the words used to conceptualize them, and the interpretations of 'instant' histories and memoirs. The third section argues that the elevation of 1939-45 in national discourse as our 'finest hour' (Churchill) has aggravated the problematic nature of I9I4-I 8 for the British. In the wake of Brexit, the last section argues that Britain - unlike France and Germany - has found it difficult to move on from the era of the two world wars by locating these conflicts in a more positive narrative of the twentieth century as the eventual triumph of European integration.

So-called 'memory booms' have become a feature of public history, as well as providing golden opportunities for the heritage industry. Yet they also open up large and revealing issues for professional historians, shedding light on how societies conceptualize and understand their pasts. ${ }^{1}$ This article explores the way that British public discourse has grappled with the First and Second World Wars. At the heart of the British problem with these two defining conflicts of the twentieth century is an inability to construct a positive, teleological metanarrative of their overall 'meaning'. By exploring this theme through historiography and memorialization, it is possible not merely to illuminate Britain's self-understanding of its twentieth-century history, but also to

Christ's College, Cambridge, CB2 3BU djrI $7 @$ cam.ac.uk

* For helpful comments on earlier versions of these arguments, the author is grateful to Kristina Spohr, Zara Steiner, and John A. Thompson and also to the anonymous referees of the Historical Journal.

${ }^{1}$ Jay Winter, Remembering war: the Great War between memory and history in the twentieth century (New Haven, CT, 20o6), esp. pp. 1-13, 275-89. 
shed light on the country's contorted relationship with 'Europe', evident in party politics and public debate right down to the 'Brexit' referendum of 2016.

The concept of mastering the past (Vergangenheitsbewältigung) originated in post-1945 West Germany as that country tried to address the horrendous legacies of Nazism. But although the German case is extreme, similar historical therapy is evident in all the countries that fought in the First and Second World Wars. Within this process, the two conflicts are intricately connected each seen refractively through the prism of the other. This methodological point is a major theme of what follows. Although the article has a comparative dimension, making reference to the experiences of other belligerent countries, its main focus is on Britain whose national obsession with the two world wars is particularly acute. The first and second section argue that British public discourse has been able to construct a satisfying narrative of 1939-45 but not of $1914^{-1} 8$. The adjective 'satisfying' signifies a story that not only has a distinct beginning, middle, and end but also an overall moral meaning. In the construction of such narratives, three important elements are identified. First, the contours of events themselves: more jagged and unsettling for Britain in the case of $1914^{-1} 8$ because of the massive death toll and also the inconclusive outcome, which necessitated a second and decisive round in 1939-45. Second, the slogans and soundbites used at the time to give meaning to those events: often these define the terms of debate for decades to come. And, third, the early historiography of those conflicts, including the war memoirs of key leaders, because instant histories of this sort often lay down enduring lines of interpretation. Section III of the article suggests that the progressive elevation in national memory since 1945 of the Second World War as our 'finest hour' has served to accentuate the problematic nature of the First World War in Britain. The last section compares British memorialization of the two conflicts with patterns in the United States, Russia, France, and Germany and argues that Britain, unlike its continental neighbours, has not been able to move on from the era of the two world wars by locating these conflicts in a transcendent account of the twentieth century as the eventual triumph of European integration. This conclusion has been underlined by the result of the Brexit referendum of 23 June 2016.

\section{I}

In the case of $1914^{-18}$, the events themselves made it hard to construct a satisfying narrative. A bloody war of attrition, with huge British losses of some

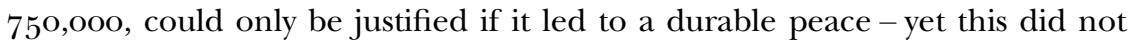
transpire. Compounding the problem, there was a paucity of compelling narrators, during the war and afterwards. The two great British memoirists, Winston Churchill and David Lloyd George, questioned the military conduct of the war and no succinct overviews were published to capture the dynamics and meaning of the conflict. By contrast, as we shall see in the second section, the events of 
1939-45 proved much less difficult to handle; furthermore, there was one supreme statesman-narrator to interpret them: Churchill himself.

For the British, the Great War started dramatically and with clear moral meaning. Not perhaps on 4 August 1914 when war was declared: recent scholarship for Britain, as for other belligerent countries, while showing the limited nature of opposition to the war, has heavily qualified the 'myth of war enthusiasm'. By 22 August, only 100,00o men had joined up. The 'key moment', argues historian Adrian Gregory, 'was the publication of the Mons Despatch in The Times on 25 August' - an official report from Sir John French, commander of the British Armies in France and Flanders, about the early battles of the British Expeditionary Force (BEF) up to the start of the retreat from the Belgian town of Mons. Official despatches were published in the London Gazette - the government's journal of record - and, as such, attracted limited attention. Republication in The Times, however, brought French's report to a much wider audience, and the impact was enhanced because the paper spun it as the story of a heroic rearguard action that highlighted the need for volunteers. Other papers picked up the story and its tone, to huge effect. In the week beginning 30 August, 175 , O00 men joined up, the figure of 33,300 on 3 September being the highest for any day of the war. ${ }^{2}$

Two points are particularly relevant here for the purposes of this article. First, we should note the importance of official despatches in shaping public understanding of the war. When it started, the secretary of state for war, Lord Kitchener, effectively treated journalists as 'outlaws' who were liable to arrest if found anywhere near the Western Front. Although in May 1915 the War Office started to accredit war correspondents, they were kept on a tight rein and allowed to see little real combat; it was not until May 1917 that newsmen were able to move relatively freely, close to the front, in an attempt to deflect mounting criticism of the casualty list. Even so, there remained a cognitive curtain between the Home Front and the Western Front which would dull public understanding of the war for years to come. Because of this strict military censorship, newspapers and the public were therefore highly dependent on official accounts of the fighting. Between August 1914 and November 1918 , the London Gazette published ten despatches about operations on the Western Front from Sir John French and a further seven from Sir Douglas Haig, who succeeded him in December 1915. Intended to form a continuous 'official public narrative of the war', these reports were reprinted by the press and proved fundamental as instant histories of events and their meaning, around which interpretations and rebuttals became encrusted. 3

${ }^{2}$ Adrian Gregory, The last Great War: British society and the First World War (Cambridge, 2008), pp. $30-3$.

3 The despatches are available online at www.1914-1918.net/despatches.htm. Quotation is from French's tenth and last despatch, published belatedly on 21 Aug. 1916. See also Martin J. Farrar, News from the Front: war correspondents on the Western Front, I9I4-I9I8 (Stroud, 1998), esp. pp. 13, $221-2$. 
Secondly, the German invasion of 'Little Belgium' gave the struggle at its outset a vivid meaning, played up by official propaganda. The Kaiser's armies had flagrantly invaded a neutral nation, which Britain had been pledged to defend. Even worse, they then flouted conventional distinctions between soldiers and non-combatants, burning the university town of Louvain and shelling the great Gothic cathedral at Reims. Reports and pictures in those opening weeks of the war had a powerful effect on British opinion: 'The Oxford of Belgium burnt by the German "Huns" declaimed the Illustrated London News; 'Holocaust of Louvain', screamed the Daily Mail. During the autumn, there were fears that the terror would spread across the Channel. The people of Essex dug trenches in preparation for possible invasion; in December, Scarborough, Hartlepool, and other east coast towns were shelled by the Kaiser's warships, killing women and children. Germany's image as 'baby killers' (Churchill's phrase) was heightened in May 1915 by the sinking of the passenger liner Lusitania, with nearly 1,200 dead.4 In the face of such evidence of 'Hunnish' militarism and barbarism - given official validation in the report on atrocities by Lord Bryce that same month-there developed a broad conviction that the British stood for freedom and civilization. The struggle was presented as essentially an issue of morality rather than self-interest, even though the fear that 'we could be next' was implicit. 5

This was the message all through the conflict - about being engaged in 'the Great War for Civilisation', to use words eventually engraved on the victory medal given to British servicemen in 1918. Although the war in 1914 was one of rapid movement, the long, bloody, muddy battle of the trenches in $19^{1} 5^{-}$ 17 produced no dramatic successes and few stories of knightly heroism to match the cadences of Rupert Brooke. Public ardour began to cool as the utterly uncivilized nature of combat became clear, with human beings reduced to troglodytes in the mud or blown to bits by those miracles of modernity, the machine gun and heavy artillery (the latter causing nearly 6o per cent of total military deaths in 1914-18). The war correspondent of The Times, Col. Charles Repington, characterized the conflict as 'the butchery of the unknown by the unseen' ${ }^{6}$ The tone of commentary also changed with the decision to introduce conscription in January 1916 , bringing Britain belatedly into line with all the continental states but also raising the question - so painful for Liberals - of whether the fight for freedom abroad could justify the use of coercion at home. 7 It is no accident that the tide of patriotic war poetry, today taken

4 Alan Kramer, Dynamic of destruction: culture and mass killing in the First World War (Oxford, 2007), p. 13; Gregory, Last Great War, p. 57.

5 For a judicious re-examination, see John Horne and Alan Kramer, German atrocities, I9 I4: $a$ history of denial (New Haven, CT, 2001), p. 419.

6 'Changing warfare', Times, 24 Nov. 1914, p. 5; cf. David Stevenson, I9I4-I9I8: the story of the First World War (London, 2004), p. 184.

7 Matthew Johnson, 'The Liberal war committee and liberal advocacy of conscription in Britain, 1914-1916', Historical Journal, $5^{1}$ (2008), pp. 399-420. 
as a hallmark of the Great War as a whole, actually ebbed in 1916 . This was not simply the reflection of a more sober public mood; many of the earlier effusions of jingoistic verse in $1914^{-15}$ had been intended to inspire recruitment. ${ }^{8}$

The battle of the Somme from July to November 1916 marks the midpoint of the war. A century on, it is the opening on 1 July that fixates the British notorious as the worst day in the history of the British Army: some 120,000 British troops took part and nearly half $(57,000)$ became casualties, of whom 19,0oo died.9 The disaster could be sensed piecemeal in the pages of dead and missing listed by local papers in towns and cities such as Accrington and Burnley, Belfast and Bradford, whose Pals Battalions had been mown down en masse, but its magnitude was concealed in official reports and the national press. In any case, the first day of the Somme was only the beginning: the battle rumbled on for another 140 days.

To bridge the information gap between the home front and the battle front, the hitherto secretive War Office commissioned a film - 'The Battle of the Somme' - which was released on 21 August 1916. Not only was it Britain's first taste of documentary war footage; more fundamentally, it seems to have provided many people with a defining sense of the war's meaning. A black and white silent movie, shot in five sections with inter-titles as brief explanation, this seventy-five-minute film seems extraordinarily crude to modern eyes. Yet some twenty million people watched it in the first six weeks and by the end of the year it had probably been seen by a majority of the British population. Reviews and comments repeatedly praised the film for its 'realism'. Frances Stevenson, Lloyd George's secretary and mistress, had lost her brother on the Western Front. After seeing the film, she wrote in her diary: 'I have often tried to imagine myself what he went through, but now I know, and I shall never forget.' ${ }^{10}$

The 'realism' was somewhat contrived: the only footage of battle, as soldiers climbed out of trench into No Man's Land, was probably filmed later behind the lines, but the image of a wounded man sliding back into the trench was recalled endlessly by viewers as one of the most graphic moments. Yet the film had the desired effect, being taken to show the sacrifice needed in order to finish the job. To quote James Cooper in The Times: 'no better means could be found of making English men and women determined to stop the repetition of such a war'. This echoed the phrase of H. G. Wells, coined in October 1914, that the aim was not just to free Belgium from 'Prussian Imperialism' but to win

\footnotetext{
8 Dominic Hibberd and John Onions, eds., The winter of the world: poems of the First World War (London, 2007), pp. xix-xx.

9 Stevenson, I9I4-I9I8, p. 170.

${ }^{10}$ Nicholas Reeves, "Through the eye of the camera: contemporary audiences and their "experience" of war in the film Battle of the Somme', in Hugh Cecil and Peter H. Liddle, eds., Facing Armageddon: the First World War experience (London, 1996), ch. 55, quoting pp. 782, 786-9o; cf. 'War's realities on the cinema', Times, 22 Aug. 1916, p. 3 .
} 
'the war that will end war' - aiming at 'a settlement that shall stop this sort of thing for ever'. Only such an outcome, it seemed, could justify such a sacrifice. ${ }^{11}$

In Whitehall, the human cost of British strategy was now being questioned by politicians, especially Churchill and Lloyd George. Whatever his private doubts, however, Lloyd George insisted in a widely reproduced press interview that 'the fight must be to a finish - to a knock-out' because the 'inhumanity and pitilessness' of the current fighting was 'not comparable with the cruelty that would be involved in stopping the War while there remains the possibility of civilisation again being menaced from the same quarter..."Never again" has become our battle cry'. A draw was probably not a real option for Britain, even in 1914 and 1915 , but after the carnage of 1916 it was politically unthinkable. The aim, one might say, was to fight to the finish but never again. ${ }^{12}$

In the event, however, the end was not the 'knock-out blow'; indeed, it was not particularly clear-cut. The German spring offensives of 1918 turned the conflict into a war of movement once more. At first, the Allies reeled back but then, from the summer, the Germans were in retreat, as losses and desertions took a massive toll on army efficiency and American troops entered combat in significant numbers. On 4 October, the shaken German High Command asked for an armistice. An armistice is, in principle, simply a ceasefire and it was negotiated with the German line almost entirely still in France and Belgium. By the time the Armistice was declared on 11 November, however, revolution had engulfed the German armed forces and toppled the Kaiser himself. On the one hand, this conveyed a vivid impression of Germany's collapse; on the other, the fighting had ended with the German army on enemy soil - fuelling claims from the political right of a 'stab in the back' (Dolchstoss).

It is worth noting that there had, indeed, been debate in the Allied High Command about carrying the war into Germany and reaching a decisive ending. On 30 October, Gen. John J. Pershing urged them to 'continue the offensive until we compel her [Germany's] unconditional surrender'; he feared that a ceasefire now would 'possibly lose the chance to secure world peace on terms that would insure its permanence'. But the general view among the military and politicians, including Lloyd George, was that they had secured a strong enough position to dictate a victor's peace and that there was no point in prolonging the carnage. To quote the Allied supreme commander, Marshal Ferdinand Foch, continuing the struggle would 'kill 50,00o or 10o,ooo Frenchmen for results that are problematical'. A policy of 'unconditional surrender' would be adopted only in the next war. ${ }^{13}$

\footnotetext{
${ }^{11}$ Reeves, 'Through the eye of the camera', pp. 785 , 791-2; H. G. Wells, The war that will end war (London, 1914), pp. 9, 11.

${ }^{12}$ John Grigg, Lloyd George: from peace to war, I9I 2-I9I6 (London, 1997), pp. 423-8, interview of 28 Sept. 1916.

13 David Stevenson, With our backs to the wall: victory and defeat in 19I8 (London, 2011),

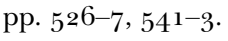


Without a clear-cut victory, the 'meaning' of the conflict turned to a large extent on the terms eventually imposed on Germany and whether they ensured an end to war. An early instant history that called this into question was John Maynard Keynes's 6o,ooo-word polemic, The economic consequences of the peace, published on 12 December 1919, which became a global bestseller. Within four months, it sold 18,5 oo copies in Britain and nearly 70,0oo in America, as well as being translated into eleven languages from German to Chinese. Keynes, who had resigned from the Treasury in disgust after his failure to cut through the tangle of war debts and reparations, blasted the Treaty of Versailles as a 'Carthaginian Peace', a 'policy of reducing Germany to servitude for a generation' and thereby causing 'the decay of the whole civilised life of Europe'. ${ }^{14}$ Keynes's lively prose and vivid character sketches had a big impact on liberal intellectuals. But as subsequent economic historians have argued, the issue was not whether Germany could pay but whether it was willing to pay. Keynes had missed an essential point: Germany in 1918 was not like Carthage after the Punic Wars. ${ }^{15}$

On the face of it, of course, the Treaty of Versailles did have the trappings of the victor's peace, with two quaking German delegates obliged to sign on the dotted line in Louis XIV's Hall of Mirrors - site of Bismarck's calculated humiliation of France in 1871 . The French staged 1919 as a deliberate act of revenge for 1871 . Yet this was the diplomatic theatre of illusions. Had France really been in a position to continue tit-for-tat diplomacy, 1919 should have been a 'Treaty of Potsdam', signed in the Kaiser's palace after a triumphal march through Berlin. To replay 1871 in Versailles therefore actually revealed the limits of Germany's military defeat in 1918. France's attempts to enforce the reparations bill imposed on Germany, including occupation of the Ruhr in 1923, represented a desperate effort to secure an economic substitute for the military knock-out that had eluded the Allies in 1918. The struggle over reparations was, to quote one German official, 'the continuation of war by other means'. ${ }^{16}$

The absence of a decisive military victory had several consequences for British public memory. For one thing, it was hard to construct any narrative of the war that rose to a dramatic and satisfying climax. The instant histories that appeared immediately after 1918 were mostly long, plodding chronologies of battles, lacking interpretative power. The most famous, published by the novelist John Buchan in 1922 under the title A history of the Great War, was a fourvolume reworking of his magazine articles during the conflict-heavy with

${ }^{14}$ John Maynard Keynes, The economic consequences of the peace (London, 1920), pp. 32, 209; Robert Skidelsky, John Maynard Keynes (3 vols., London, 1983-200o), I, pp. 393-4.

15 Niall Ferguson, The pity of war (London, 1998), pp. 412-19.

16 Sally Marks, 'Smoke and mirrors: in smoke-filled rooms and the Galérie des Glaces', in Manfred F. Boemeke, Gerald D. Feldman, and Elisabeth Glaser, eds., The Treaty of Versailles: a reassessment after 75 years (Cambridge, 1998), p. 338; see also Albrecht Ritschl, 'The pity of peace: Germany's economy at war, 1914-1918 and beyond', in Stephen Broadberry and Mark Harrison, eds., The economics of World War I (Cambridge, 2005), esp. pp. 66-8. 
events, light on analysis and cautiously positive about the future. No one struggling through these volumes would gain much sense of what the war had been about. They might have hoped to do so from Basil Liddell Hart's The real war (1930), but he offered a very partial and partisan view of the conflict, focused on strategy and operations. Liddell Hart was preoccupied with the Western Front and even then deliberately raced over the climactic battles in France in 1918 to ram home his idée fixe that the naval blockade, not Haig's army, had been 'the decisive agency' in winning the war. A history of the Great War (1934) by the Oxford historian and war veteran Charles Cruttwell was less openly opinionated and had more to say on soldierly experience but it was even more narrowly concerned with military operations than Liddell Hart's volume. ${ }^{17}$

For a clear narrative arc, one would have to turn not to history books but to Haig's final despatch published on 8 April 1919. This artfully composed document claimed that 'the long succession of battles commenced on the Somme in 1916 and ended in November of last year on the Sambre' should be 'viewed as forming part of one great and continuous engagement'. Paying attention to 'any single phase of that stupendous and incessant struggle' would 'risk the formation of unsound doctrines regarding the character and requirements of modern war'. This rubric allowed Haig to slide over the losses and tactical errors of the Somme and Passchendaele and to develop a teleological account of the slow, deliberate build-up of attrition, insisting that 'the rapid collapse of Germany's military powers in the latter half of 1918 was the logical outcome of the fighting of the previous two years'. Haig strenuously contested what was by then the widespread view that modern firepower had made attack 'more expensive than defence', on the casuistic grounds that this judgement was only true if the offensive was 'unsuccessful'. The basic arguments of his despatch were developed as a two-volume account of Sir Douglas Haig's command, written by two of his staff officers and published in 1922, which presented Haig's strategy from the time he took over at the end of 1915 as a consistent policy of 'killing Germans in a war of attrition' through repeated offensive operations. ${ }^{18}$

This smooth apologia for attrition provoked forceful rejoinders from the two great political memoirists, Churchill and Lloyd George - each of whom devoted six volumes to his version of the Great War. Churchill went head to head with attrition in his third volume (published in March 1927) in a chapter entitled 'The blood test', which he personally considered 'probably the most important chapter of the book'. This was built around relative casualty figures - using data

${ }_{17}$ B. H. Liddell Hart, The real war, I9I4-I9I8 (London, 1930), p. 503. See also Hew Strachan, "The real war": Liddell Hart, Cruttwell, and Falls', in Brian Bond, ed., The First World War and British military history (Oxford, 1991), pp. 41-67.

${ }^{18}$ Haig, 'Final despatch, part II (features of the war)', 8 Apr. 1919 - available at www.19141918.net/haigs_final_despatch.html. See also G. A. B. Dewar and J. H. Boraston, Sir Douglas Haig's command, December I9, I9I5-November I I, I9I8 (2 vols., London, 1922). 
obtained from the British official historians and from the Reicharchiv in Berlin via his friend Lord D'Abernon, Britain's ambassador to Germany. Churchill deployed these statistics to critique the Haig camp's depiction of victory on the Western Front as the unfolding of 'a grand design, measured, foreseen and consciously prepared'. Yes, he said, in $1915^{-17}$ 'the process of attrition was at work, but it was on our side that its ravages fell, and not on the German' - with the British and French suffering nearly twice the number of casualties than the enemy. This pattern was reversed only when Ludendorff and the Germans moved onto the attack in the spring of 1918: 'It was their own offensive, not ours, that consummated their ruin.' 19 Although Churchill's 'blood test' was crude and his calculations have been contested by recent British military historians, this was an impressive piece of analysis for that time. Moreover, Churchill's essential point is now widely accepted. Ludendorff made serious strategic and tactical errors in the spring of 1918 but his root problem was going onto the offensive: once he did so, it was the beginning of the end for the German army. ${ }^{20}$

Lloyd George's six volumes were published later, between 1933 and 1936 , but the time-lag proved beneficial for him because of the mass of writings on the war that had now appeared and the greater authorial freedom provided by the death of Haig in 1928 . Lloyd George mounted a vituperative attack on Haig's strategy of attrition, supported by a tranche of official documents secretly provided by the cabinet secretary, Sir Maurice Hankey. The latter shared Lloyd George's strategic inclinations but did not approve of his often caustic tone, urging him to 'stand as far as possible on the documents and avoid the jibes'. This provoked a splenetic reply: 'for 15 years I have borne with a stream of criticism, polluted by poisonous much antagonism', from the memoirs of generals, admirals 'and their minions' using 'bowdlerized, distorted quotations'. Lloyd George declared that he now owed it to 'public and posterity' to 'tell the whole truth'. ${ }^{21}$ His main target was not the Somme in the second half of 1916 but the Third Battle of Ypres in the second half of 1917 , generally known to the British by the haunting name of Passchendaele after the village and ridge that were its initial objectives. The campaign became nonsensical when torrential rain, compounded by Allied shelling, turned the ground into a quagmire - from which our most stereotypical images of the Western Front

19 Churchill to Edmonds, 29 Aug. 1926 and 18 Sept. 1926 (quotation), Churchill papers, CHAR 8/203, fos. 67 and 81 (Churchill Archives Centre, Cambridge); Winston S. Churchill, The world crisis, I9I6-I9I8, part I (London, 1927), ch. 2, quoting pp. 45, 54-5, 57 .

${ }^{20}$ Robin Prior, Churchill's 'world crisis' as history (London, 1983), pp. 221-30; William Philpott, Bloody victory: the sacrifice on the Somme (London, 2009), pp. 596-6o3; cf. Ferguson, Pity of war, pp. 292-303; Alexander Watson, Ring of steel: Germany and Austria-Hungary at war, I9I4-I9I8 (London, 2015), pp. 514-23.

${ }^{21}$ Hankey to Lloyd George, 16 Apr. 1934, with comments on Passchendaele chapter, and Lloyd George to Hankey, 18 Apr. 1934, Lloyd George papers, G/212 (House of Lords Record Office). See generally George W. Egerton, 'The Lloyd George War memoirs: a study in the politics of memory', Journal of Modern History, 6o (1988), pp. 55-94. 
derive. Yet Haig persisted, against the advice of almost all his commanders, until December, concealing the true situation from politicians and the public at home. Lloyd George devoted $16_{5}$ pages of volume IV to Passchendaele, lauding the Tommies and skewering Haig: the campaign, he said, illustrated 'the unquenchable heroism that will never admit defeat and the inexhaustible vanity that will never admit a mistake'. Passchendaele, he asserted, was 'one of the greatest disasters of the War'. Lloyd George's account, though full of its own deceptions and half-truths, has defined the terms of debate about Haig's strategy ever since. ${ }^{22}$

Lloyd George's memoirs also offered readers some of the sharpest summaries of how the war was won, for instance in his preface to the final volume, published in November 1936. 'The World War ended', he stated firmly, 'in a victory for Right. But it was won not on the merits of the case, but on a balance of resources and blunders.' By that, Lloyd George meant that the Allies possessed men, money, and materiel on a scale 'overwhelmingly greater' than the enemy. As for errors: 'Both sides blundered badly, but the mistakes committed by the Central Powers were the more fatal, inasmuch as they did not possess the necessary resources to recover from the effects of their errors of judgment'. In other words, 'the blunders of Germany saved us from the consequences of our own'. So much for Haig's grand design: that smooth, well-planned two-year march to inevitable triumph. For Lloyd George it was actually a 'bloodstained stagger to victory'. ${ }^{23}$

Lloyd George's memoirs were widely read in the mid-193os - the cheap, twovolume edition published in 1938 sold 100,ooo copies in just six months - and also extensively serialized in newspapers. Yet they probably did not alter general public perceptions of the war's meaning - already set by the early 1920 - which did not turn on statistical tables and strategical debates. Most families could see from the names on the war memorials and the disabled veterans on the streets that the war had been an immense 'sacrifice' - to quote the sacramental language generally used. The nature of that sacrifice was being described more graphically by the end of the 1920 , with a rash of tenth-anniversary memoirs about the experience of soldiers rather than the apologetics of generals, but most writers did not preach a stark pacifist message. War was hell - that was axiomatic - but Britain had emerged victorious and few people would go so far as to assert that the Great War had been pointless, if only out of respect for the dead and the bereaved. When King George V opened the new Imperial War Museum (IWM) in 1920 he expressed the hope that, 'as a result of what we have done and suffered', posterity might 'be able to look back on war, its instruments, and its organisation as belonging to a dead past'. In other words, the IWM

${ }^{22}$ David Lloyd George, War memoirs (6 vols., London, 1933-6), IV, pp. 2110 , $225^{1}$; Brian Bond, The unquiet Western Front: Britain's role in literature and history (Cambridge, 2002), pp. $4^{6-8 .}$

${ }^{23}$ Lloyd George, Memoirs, vI, p. xiii, III p. xi. 
should be a museum not just of war but for war. Turning war into history would be the ultimate justification for the sacrifice of $1914-18 .^{24}$

By the 1930s, amid the disillusion of the slump, this message became ubiquitous, even in the forms of remembrance. In November 1933, the cover of the British Legion Journal featured a statue of a mother holding the body of her dead son, with the words 'disarm' on the plinth. And so at the Menin Gate in Ypres, the Cenotaph in Whitehall, and at hundreds more memorials across Britain, people enacted an annual ceremony of remembrance that, to quote historian Adrian Gregory, 'managed to remain ambivalent' - a 'death cult which idealised the young "fallen" as patriots but which also underlined the new idealism: "Never again". ${ }^{25}$ In the early 1930s, Britain had the largest peace movement in the world, spearheaded by the League of Nations Union - a unique pressure group of which the honorary president was automatically the country's serving prime minister. This yearning for peace was expressed in manifestations widely derided today, such as the 'Peace Ballot' of 1935, which was completed by 11.6 million people (over a third of the UK population) and the ecstatic relief when Neville Chamberlain returned from Munich in September $193^{8}$ proclaiming 'peace for our time'. These forms of 'appeasement' need to be understand as a desperate effort to give meaning and permanence to the sacrifice of $1914^{-18} .^{26}$

Yet the effort proved in vain. 'One could hardly keep from crying', Nurse E. M. Selby noted on Armistice Day 1918, 'when one thought of all the boys who would never be coming home.' That was the last entry in her diary of the Great War. She picked up her pen again on 7 June 1940, just after the evacuation from Dunkirk, with the laconic words: 'Another war. Same enemy.' ${ }^{27}$

So much for 'Never Again'.

\section{I}

The war of 1939-45 developed very differently for the British from that of 1914-18. Historiographically, the result was a much more compelling narrative with a clear beginning, middle, and end - each phase of which was suffused in drama and informed with moral meaning. Although this narrative emerged naturally from events, which were far less painful and confusing than those of the Great War, it was also shaped from an early stage by Churchill through his prime

\footnotetext{
24 Egerton, 'Lloyd George War memoirs', p. 79; the king's speech of 9 June 1920, quoted in

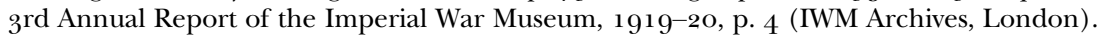

25 Adrian Gregory, The silence of memory: Armistice Day, I919-1946 (London, 1994), pp. 123, 126.

26 David Reynolds, The long shadow: the Great War and the twentieth century (London, 2013), pp. 21 7-23, 228-9; see also Helen McCarthy, The British people and the League of Nations: democracy, citizenship and internationalism (Manchester, 2011).

27 Gregory, Last Great War, p. 275.
} 
ministerial speeches during the war and his memoirs soon afterwards. The latter set firm the still-prevailing narrative of what we might call Britain's 'good war'. ${ }^{28}$

Although the conflict began on 3 September 1939, the Western Front saw no significant action all through the winter - a period known in Britain as the 'Twilight War'. But when the real war started in the spring of 1940, it careered off on a totally different course from the Great War. Whereas the Western Front had lasted four full years in 1914-18, it survived barely four weeks in 1940 before the French sued for an armistice. The summer of 1940 gave Britain's second war a luminous centre that, as we have seen, was lacking in 1914-18. This emerged very quickly at the time and has been little dimmed or tarnished thereafter, unlike the waves of revisionism about the Great War. The now familiar British account of 1940 comprises three dramatic moments Dunkirk, the Battle of Britain, and the Blitz - each of which was treated in heroic, historic, and populist language largely absent from the discourse about the Great War. ${ }^{29}$

Churchill the speech-maker helped define this narrative, not just through his famous sound-bites but also via instant historical analysis. On 18 June, for instance, he crafted the labels 'the Battle of France' and 'the Battle of Britain', which continue to frame accounts of the conflict, as well as predicting that 1940 would be seen as Britain's 'finest hour'. His address on 20 August coined the term 'the Few' about the RAF and also distinguished this conflict from its predecessor - involving 'not just soldiers, but the entire population, men, women and children'. $3^{\circ}$ Churchill's war speeches, some of which were relayed to the public over the radio in a way not possible in $1914^{-18}$, are usually venerated as peerless oratory. On close inspection, however, many were long, detailed, and unexciting. Their value was often informational not inspirational - for a public and press overwhelmed with facts and images about the war (in contrast with Britain in 1914-18) providing a clear overall narrative framework that was otherwise lacking. Churchill's speeches may be seen almost as exercises in contemporary history, drawing on his long experience as a newspaper columnist and commentator. Take, for instance, his address to the Commons on 4 July about the Royal Navy's sinking of the French fleet after the armistice. To quote the US military attaché in London, who listened to the prime minister from the Gallery: 'with the most dramatic effect and yet

${ }^{28}$ For a pioneering exploration of this theme, see Jose Harris, 'War and social history: Britain and the Home Front during the Second World War', Contemporary European History, 1 (1992), pp. 17-35.

${ }_{29}$ For studies of these themes, see Angus Calder, The myth of the Blitz (London, 1991); Malcolm Smith, Britain and I940: history, myth and popular memory (London, 200o); Mark Connelly, We can take it! Britain and the memory of the Second World War (London, 2004); and Sonya Rose, Which people's war? National identity and citizenship in Britain, 1939-1945 (Oxford, 2003).

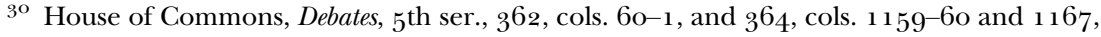
18 June and 20 Aug. 1940. 
with the most superb composure, he narrated as a historian this vivid passage of history'. ${ }^{1}$ Churchill's ability to provide compelling narrative is a neglected feature of his war speeches, most of which were actually read in newspapers by the British people rather than heard on the radio.

But Churchill's narration did not stand alone: pundits, commentators, and newsreels also shaped the saga of 1940. The first ingredient was a sense of the heroic. The classical language of heroism had been evident in 1914, most famously in the poems of Rupert Brooke, and it never disappeared from the daily poetry offerings in The Times during the Great War. But heroism was not the refrain of Siegfried Sassoon or Wilfred Owen, nor was it a feature of the writing about the war in the 1920 s and 1930s. In 1940, by contrast, heroes were back with a vengeance and they were to be found not in the trenches but in the air. The place in history of Churchill's 'Few' was confirmed by a special thirty-page pamphlet on 'The Battle of Britain' (also his phrase) published by the Air Ministry in March 1941. Sales were expected to be about 50,ooo but within the first month more than one million copies had been sold, orders for the illustrated edition had reached half a million and the pamphlet was soon translated into several languages. The story recounted was not of earthbound combat, vintage 1916 - shells, smoke, noise, and 'avalanches of earth' - but 'a duel with rapiers' thousands of feet up in the air, 'fought by masters of the art of fence'. The Battle of Britain was also represented as a struggle of epic importance: 'Future historians may compare it with Marathon, Trafalgar and the Marne' (the reference to Trafalgar being omitted when the pamphlet was translated into French). 'More than anything else', writes historian Richard Overy, this little booklet ' gave the conflict the legendary dimensions it has borne ever since'. ${ }^{2}$

Buttressing the heroic was a sense of the historic. Again, this emerged very quickly: on 25 May 1940, The Times coupled the struggle for the Channel ports with epic moments of English history-Agincourt, the Armada, Waterloo, and also the battle fought by 'Haig's men' in March 1918. After the Dunkirk evacuation, Churchill observed to the Commons: 'We are told that Herr Hitler has a plan for invading the British Isles.' He then added 'this has often been thought of before', most recently by Napoleon. In the peroration to his speech, Churchill declared his full confidence that 'we shall prove ourselves once again able to defend our island home, to ride out the storm of war, and to outlive the menace of tyranny, if necessary for years, if necessary alone'. That last word became a British catchphrase in the summer of 1940. 'Very Well, Alone', David's Low's now celebrated cartoon of 18 June after the Fall of France, depicted a Tommy, fist in the air, defying the

$3^{1}$ Richard Toye, The roar of the lion: the untold story of Churchill's World War II speeches (Oxford, 2013), pp. 62-3.

32 'The Battle of Britain: an Air Ministry account of the great days from 8th August -31 st October 1940' (London, 1941), pp. 4-5, 35; Peck to Peirse, 6 Apr. 1941, London, The National Archives (TNA), Air Ministry papers, AIR 19/258; Richard Overy, The battle (London, 2000), pp. 130-1. 
storm-tossed seas. 'Now we know where we are!' shouted the skipper of a Thames tug-boat: 'No more bloody allies!'33 T. S. Eliot captured the incandescence of the moment with the line 'History is now and England', in the last of his 'Four Quartets', composed while fire-watching during the Blitz. Eliot's words would have been inconceivable during the Great War: more likely in September 1914 'History is now and Belgium.'34

The war of 1940 was also a struggle involving all the people. The populist inclusivity of the heroic national narrative constitutes the third big contrast with the Great War. In his BBC radio 'Postscript' on 5 June 1940, the author J. B. Priestley singled out the part played in the improvised evacuation by 'little pleasure steamers' such as the Gracie Fields, which he recalled affectionately as a pre-war ferry shuttling between Cowes and the Isle of Wight. She and many of 'her brave and battered sisters' were now gone forever, sunk by German bombs, but, concluded Priestley, 'our grandchildren, when they learn how we began this War by snatching glory out of defeat, and then swept on to victory, may also learn how the little holiday steamers made an excursion to hell and came back glorious'. Priestley's picaresque vignette was a masterstroke and it set the tone for how Dunkirk has been remembered. A leading article in The Times the following day, 6 June 1940, was already encouraging readers to draw inspiration from what it called 'the spirit of Dunkirk'.35

This populist theme of the 'people's war' (a term first propagated by leftist veterans of thirties Spain) was expressed most of all in the Blitz, when the front-line heroes were civilians. During the first three years of the war, until late 1942, more British women and children were killed by the enemy than British soldiers - a remarkable contrast with 1914-18. The trenches of this war were not dug in the mud of the Somme and Flanders but carved from the rubble of London and Manchester. The Blitz's enduring images, already featured on the newsreels and in journals such as Picture Post, were of a fireman, high on his ladder, courageously playing his hose into a burning building, or of families dossing down for the night on the platform of an Underground station. The Blitz became 'a key moment in the war' - when 'the people' were incorporated into 'the nation'. $3^{6}$

This vivid saga of 1940 - heroic, historic, and populist - became effectively the real starting point of Britain's second war, a pattern enhanced as the

33 Times, 25 May 1940, p. 7; Commons, Debates, 361, cols. 792, 795, 4 June 1940; Connelly, We can take it!, p. 66; Angus Calder, The people's war: Britain, 1939-1945 (2nd edn, London, 1971), p. 130.

34 'Little Gidding', in The collected poems and plays of T. S. Eliot (London, 1969), p. 197; Peter Ackroyd, T. S. Eliot (London, 1985), pp. 263-4.

35 J. B. Priestley, Postscripts (London, 1940), p. 4; Times, 6 June 194o, p. 7. See also Siân Nicholas, "Sly demagogues" and wartime radio: J. B. Priestley and the BBC', Twentieth Century British History, 6 (1995), pp. 247-66.

${ }^{36}$ Richard M. Titmuss, Problems of social policy (London, 1950), pp. 335-6; Connelly, We can take it!, p. 142; Lucy Noakes, War and the British: gender, memory and national identity (London, 1998), pp. 26, 29. 
American term 'Phoney War' gained currency to label the winter of 1939-40. Yet effective narratives require not only a start but also a middle and an end: here too clear markers were laid down at the time.

After the heady days of 1940, the next two years saw a succession of British defeats and retreats - Greece, Crete, Singapore, and Tobruk. People joked grimly that the acronym for the British Expeditionary Force - BEF - meant 'Back Every Friday'. Churchill placed much of the blame on his generals, and with some justice. Undoubtedly, they were slow to master the combined arms tactics - tanks, infantry, artillery, and aircraft - that the Germans had displayed so successfully in 1940. But, more deeply, this was an army still scarred by the Great War. Sir Alan Brooke, chief of the Imperial General Staff, wrote in his diary in March 1942:

Half our Corps and Divisional Commanders are totally unfit for their appointments, and yet if I were to sack them I could find no better! They lack character, imagination, drive and power of leadership. The reason for this state of affairs is to be found in the losses we sustained in the last war of all our best officers, who should now be our senior commanders. 37

Mindful of the Great War, Brooke and his colleagues were also sure that they could not drive their troops too hard. Units were given carefully defined tasks and told to consolidate their gains rather than push on opportunistically: the initiative allowed to junior commanders in the German army was alien to British military doctrine. Fearful of brittle morale and conscious of Britain's limited manpower reserves, battlefield tactics relied on heavy firepower to undermine enemy resistance. 'We have got to try and do this business with the smallest possible casualties', Gen. Bernard Montgomery remarked in $1944.3^{8}$

Monty - the supreme exponent of careful, set-piece engagements - won his place in British history by defeating Rommel's German-Italian army at Alamein in November 1942. The battle itself was a limited affair, with roughly 5 , ooo dead on both sides. This was dwarfed by the million or so lost by the Russians and the Germans in the contemporaneous Stalingrad campaign, which proved the true turning point of the land war in Europe. But Monty and Alamein became household names across Britain because of the immense domestic political importance of the victory after two years of morale-sapping defeats that had raised questions about Churchill's continued leadership. Twice in six months, the prime minister had faced votes of no confidence in the House of Commons and his trademark symbols of defiance now seemed less impressive than in 1940: 'If only he'd keep those great gross cigars out of his face', noted one peeved diarist. Little wonder that, after Alamein and the near simultaneous Anglo-American invasion of French

37 Winston S. Churchill, The Second World War (6 vols., London, 1948-54), Iv, pp. 343-4, 352, 378; Lord Alanbrooke, War diaries, I939-1945, ed. Alex Danchev and Daniel Todman (London, 2001), p. 244.

$3^{8}$ David French, Raising Churchill's army: the British Army and the war against Germany, I9I9I945 (London, 200o), pp. 242-6, 274-85, quoting Monty on p. 245 . 
north-west Africa, the prime minister ordered the ringing of church bells, silent since the Battle of Britain. As in 1940, Churchill the wordsmith gave instant historical form to the molten chaos of war, describing what he dubbed the 'Battle of Egypt' as not 'the end' or 'even the beginning of the end' but 'perhaps, the end of the beginning'. Alamein was a visible and unequivocal victory occurring at what proved to be the midpoint of the war. By contrast, the midpoint of the Great War was the battle of the Somme. Although there is now much evidence that this seriously sapped the strength and morale of the German army, that was not clear at the time. In 1916, the Allies advanced no more than seven miles. Much more obvious were the huge British casualties: 420,0oo killed, wounded, and missing. The Somme could not be spun as a success, whereas Alamein, followed by the Germans' steady retreat to Tunis, was plausibly hyped as a decisive victory. 39

This was also a war waged with a different cast of allies from that of 1914-18. This time, the French played only a minor role because of their defeat and humiliation in 1940. Henceforth, to the fury of the Free French leader, Gen. Charles de Gaulle, they were repeatedly marginalized by Churchill and especially Roosevelt. In his war memoirs, published in 1956, de Gaulle penned a colourful account of his fierce exchange with the prime minister on 4June 1944 when belatedly informed of the impending landings in Normandy. 'There's something you need to know', Churchill exclaimed in anger: 'each time we must choose between Europe and the open sea (le grand large), we shall always choose the open sea. Each time I must choose between you and Roosevelt, I shall always choose Roosevelt.' $4{ }^{\circ}$ Whether or not Churchill used those exact words, they certainly express his priorities during and after the war. He only started using the term 'special relationship' in public in 1943 but it was his lode-star right from the day he took office in May 1940. American resources and manpower proved essential to British victory: Lend-Lease, for instance, covered more than half of the country's balance of payments deficit during the war and by early 1945 the United States provided two-thirds of the Allied troops on the Western Front. Also important was the contribution of the British Empire and Commonwealth, with the so-called 'White Dominions' gaining more attention than the (larger) forces of the Indian Army. In the autumn of 1940, two Canadian divisions served in southern England as part of the front line against possible invasion. At Alamein in 1942, 4 o per cent of the victorious 'British' infantry were actually from Australia, India, New Zealand, and South Africa. Although to a large extent the land war in Europe in 1941-5 was decided by the Red Army, it was the contribution of the

39 Max Hastings, Finest years: Churchill as warlord, 1940-1945 (London, 2009), p. 302; Niall Barr, Pendulum of war: the three battles of Alamein (London, 2004), pp. xxxvii, 404-7; Philpott, Bloody victory, pp. 6oo-3.

$4^{\circ}$ Charles de Gaulle, Mémoires de guerre: l'unité (1942-1944), in de Gaulle, Mémoires (complete edn, Paris, 2000), pp. $4^{8} 7^{-8}$. 
'English-speaking Peoples' - another phrase popularized by Churchill - that lodged itself in British public memory. ${ }^{4^{1}}$

The British Army did not return to France until almost exactly four years after Dunkirk but D-Day on 6 June 1944 marked the beginning of the end for Nazi Germany. Although Allied progress in the West was erratic-bogged down in Normandy in July 1944, stalled on the Rhine during the following winter overall, $1944^{-5}$ saw an advance that contrasted markedly in pace and penetration to the Western Front in $1915^{-18}$. Thanks to the British emphasis on firepower not manpower, in 1939-45 total British Army casualties (killed, missing, and wounded) amounted to 366 ,ooo; for the Western Front alone in $1914^{-1} 8$ the figure had been at least 2.5 million. $4^{2}$ And the war ended in May 1945 with Germany's complete capitulation, the occupation of all its territory and the death of the Führer-unlike November 1918 when the war stopped with the German army still on foreign soil and the Kaiser was allowed to slip away into his Dutch exile. The policy of 'unconditional surrender', touted by Pershing in 1918, had been pressed on the Allies by President Franklin D. Roosevelt, who was determined to avoid any repetition of German propaganda about a 'stab in the back'. Little wonder that Churchill ordered that the end of hostilities in Europe should not be called 'Armistice Day' or 'Cease Fire Day' but 'Victory Day'.43

With victory also came vindication, as the advancing Allies exposed the horrors of the German death camps, especially Bergen-Belsen. Although not an extermination camp like Auschwitz and others liberated by the Red Army, Belsen contained over 40 , ooo people, most of them suffering from acute malnutrition and disease, together with some 10,0oo decomposing corpses littered around the excrement-filled compounds. Its horrors were exhaustively documented by British Army film crews, whose thirty-three rolls of film and over 200 photographs have been described as 'arguably the most influential of any record or artefact documenting the Nazi concentration camps'.44 Despite decorous editing, the grisly images had an overwhelming impact when shown in British cinemas in the spring of 1945 . 'Everybody everywhere, in the tram, in the office', according to one diarist, was 'talking about the German atrocities now being uncovered and really, our wildest imaginings couldn't have pictured things as bad as they are.' The larger moral was underlined by 'Horror in our time' - a newsreel distributed by Gaumont British News in April 1945 - which

$4^{1}$ Reynolds, Long shadow, pp. 272-3; James K. Sadkovich, 'Understanding defeat: reappraising Italy's role in the Second World War', Journal of Contemporary History, 24 (1989), p. $4^{6 .}$

$4^{2}$ John Ellis, Cassino: the hollow victory (London, pbk edn, 2003), p. 222 ; John Ellis, World War II: the sharp end (London, 1980$)$, p. $15^{6 .}$

43 A point made clear in the cabinet secretary's notes of the meeting on 9 Apr. 1945, TNA, $\mathrm{WM}_{41}$ (45) 6, CAB 195/3, pp. $85^{-6 .}$

44 Toby Haggith, 'The filming of the liberation of Bergen-Belsen and its impact on the understanding of the Holocaust', in Suzanne Bardgett and David Caesarani, eds., Belsen 1945: new historical perspectives (London, 2006), p. 89. 
interspersed footage from the camps with shots of 1940 while the commentator observed: 'Never forget, but for the Battle of Britain this might have been you.' 45 Here were atrocities on a scale and character that dwarfed anything from Belgium in 1914, endowing the war of 1939-45 with a moral clarity that the British did not perceive in $1914^{-18}$.

By 1945, therefore, a clear and compelling narrative of the conflict had already emerged - with a dramatic start in 1940, a precise turning point in 1942, and a clear, moral ending. In the process, the story of the decades since 1918 had also been cast in a new and sombre light. The tone was set in 1940 by Guilty men-a ferocious polemic published only two weeks after France had surrendered under the pseudonym 'Cato' by three left-wing journalists - including Michael Foot, a future leader of the Labour party. Starting on the beaches of Dunkirk, it told 'the story of an Army doomed before they took the field' and tracked back over the 1930 os to find the culprits. The indictment was stark: 'MacDonald and Baldwin took over a great empire, supreme in arms and secure in liberty' and then 'conducted it to the edge of national annihilation', abetted by the 'umbrella man' Neville Chamberlain. Their blindness about Hitler and their failure to rearm, argued Cato, had left Britain criminally unprepared for the Blitzkrieg unleashed in May 1940. Guilty men

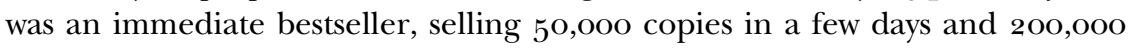
by the end of 1940. It set the agenda for subsequent debates about appeasement, rather as Keynes's Economic consequences of the peace in 1919 has shaped popular perceptions of the Treaty of Versailles. Guilty men nailed Chamberlain's reputation into a coffin from which it has still not escaped. $4^{6}$

In the election of July 1945, when Labour won a landslide victory, its manifesto set out a succinct radical narrative linking the two world wars, and revolving around 1940. 'So far as Britain's contribution is concerned', it argued, 'this war will have been won by its people.' The same was true of the last war but after 1918 the people had allowed 'the hard-faced men who had done well out of the war' to craft 'the kind of peace that suited themselves.' They controlled the government and the economy, not just in Britain but across the industrialized world, and the great interwar slumps were the direct result of leaving 'too much economic power in the hands of too few men'. Similar forces were at work in 1945, Labour warned. 'The problems and pressure of the post-war world threaten our security and progress as surely as - though less dramatically than - the Germans threatened them in 1940. We need the spirit of Dunkirk and of the Blitz sustained over a period of years.' On election morning, the pro-Labour Daily Mirror told readers: 'Vote on behalf of the men who won the victory for you. You failed to do so in 1918. The result is known to all.'

45 Tony Kushner, The Holocaust and the liberal imagination (Oxford, 1994), p. 210 ; Haggith, 'Filming', p. 110.

$4^{6}$ 'Cato', Guilty men, ed. John Stevenson (London, 1998), pp. xv, 14, 17, 45; cf. Julie V. Gottlieb, 'Guilty women', foreign policy, and appeasement in inter-war Britain (Houndsmill, 2015 ). 
The paper devoted most of its front page to a Zec cartoon showing a weary, battered soldier holding out the laurel wreath of 'Victory and Peace in Europe'. The caption read: 'Here You Are - Don't Lose it Again.'47

So 1940 became central to a new national myth. Not, like Gallipoli for the Australians, a myth of national 'discovery' but a story of 'rediscovery', when a country that had lost its way after the lost peace regained its identity and purpose in the crucible of the people's war. In Charles Mowat's mammoth history of Britain between the wars, I9I8-1940, published in 1955, the final section was headed simply 'Alone'. In the summer of 1940, Mowat asserted, as the British people awaited the Battle of Britain 'they found themselves again, after twenty years of indecision. They turned from past regrets and faced the future unafraid.' The phrase 'twenty years of indecision' was part of the increasing tendency to bracket off the 1920 s and 1930 os as the 'inter-war years' - suspended dolefully between two great conflicts. Having to wage the struggle all over again set the whole of British history since 1914 in a totally different light. $4^{8}$

One can also see this in the nomenclature for the two conflicts. The Germans and the Americans always referred to $1914^{-1} 8$ as 'the world war' (Weltkrieg) but the British almost always called it 'the Great War', echoing the twenty-year struggle against France in the era of Napoleon. After 1939, the predominant British label for the new conflict was simply 'the War' but in 1944, the publishers Macmillan asked for official guidance, noting that many American publications were employing the terms 'First World War' and 'Second World War'. The cabinet secretary Sir Edward Bridges admitted that 'Great War' did seem 'pretty inappropriate now', but no official decision was made until January 1948 when the Cabinet Office was asked to confirm a title for the impending series of official histories of the war. Eschewing alternatives such as 'the Six Years' War', it decided to follow the American convention, which Churchill was also adopting for his war memoirs. Clement Attlee, the prime minister, gave his approval and so the British government finally decided, two and a half years after the guns fell silent, that it had been fighting 'the Second World War'.49

The point here is not mere semantic trivia. The term 'Great War' had placed $1914^{-18}$ on a pinnacle of its own: the struggle of $1792-1815$ against France, from which the name had been taken, occurred a century earlier. But to say

47 Labour party, Let us face the future (1945) - www.labour-party.org.uk/manifestos; Daily Mirror, 5 July 1945 , p. 1.

$4^{8}$ Calder, Myth of the Blitz, p. 7; Charles Loch Mowat, Britain between the wars, I9I8-1940 (London, 1955), pp. 656-7; see also John Baxendale and Christopher Pawling, Narrating the thirties: a decade in the making, I9zo to the present (London, 1996).

49 TNA, CAB 103/286, quoting Bridges to Martin, 24June 1944, and TNA, CAB 134/105, meeting of 21 Jan. 1948, minute 7, and Attlee's endorsement, 27 Jan. 1948; see also David Reynolds, 'The origins of "the Second World War": historical discourse and international politics', Journal of Contemporary History, 38 (2003), pp. 29-44. 
that 1914-18 was simply 'the First World War', a quarter century before the next, suggested a very different narrative arc, which relegated that first conflict to the status of an opening round in a struggle that was finished off conclusively only in round two. The concept of a 'twenty years' crisis' from 1919 to 1939, used without explanation by E. H. Carr in $1939,5^{\circ}$ was developed by other writers, particularly Churchill. In the preface to his first volume of war memoirs, the former prime minister presented them 'as a continuation of the story of the First World War' which he had composed in the 1920s. Taken together, he stated, the two sets of memoirs 'will cover an account of another Thirty Years War'. Linking $1914^{-18}$ and 1939-45 in this way into an overarching 'Thirty Years War' would become a familiar trope of subsequent pundits and historians. ${ }^{1}$

Churchill's memoirs, like his war speeches, also helped enormously to frame the British narrative. These six volumes, published between 1948 and 1954, offered vivid personal vignettes of key moments and meetings of the war, buttressed by a mass of official documentation that ordinary historians, under the rules then current, could not have hoped to get their hands on until the twenty-first century. Their impact owed something to the speed of production: the first three volumes, taking the story up to Pearl Harbor at the end of 1941, appeared within five years of the end of the conflict, enabling Churchill to establish his interpretation on Britain's war before anyone else - in marked contrast with Lloyd George's belated take on the First World War. This was truly instant contemporary history, and much of it has endured. Even in the twenty-first century, the British tend to follow the phases and the phrases by which Churchill structured events. The gathering storm, for instance, on the period 1919-39, was built around the theme of 'how the English-speaking peoples, through their unwisdom, carelessness and good nature, allowed the wicked to rearm'. Title and theme together encapsulate what has become the British authorized version on appeasement. Volume II was pegged to his speech of 18 June 1940 but now with the rhetoric of hope transmuted into a statement of fact: 1940 simply was Their finest hour. The other volume titles still recur in conceptualizations of the war: The grand alliance, The hinge of fate, Closing the ring, Triumph and tragedy. And so J. H. Plumb's observation in 1969 about Churchill's memoirs holds good today: we still 'move down the broad avenues which he drove through war's confusion and complexity'. $5^{2}$

$5^{\circ}$ See Edward Hallett Carr, The twenty years' crisis, I919-1939: an introduction to the study of international relations (2nd edn, London, 1946), p. 224; Jonathan Haslam, The vices of integrity: E. H. Carr, I892-I982 (London, 1999), pp. 68-9.

$5^{1}$ Churchill, Second World War, I, p. vii. See also P. M. H. Bell, The origins of the Second World War in Europe (London, 1986), chs. 2-4; and Michael Howard, 'A Thirty Years War? The two world wars in historical perspective', Transactions of the Royal Historical Society, 6th ser., 3 (1993), pp. 171-84.

$5^{2}$ Churchill, Second World War, I, p. ix; J. H. Plumb, 'The historian', in A. J. P. Taylor et al., Churchill: four faces and the man (London, 1969), p. 149. See also David Reynolds, In command of history: Churchill fighting and writing the Second World War (London, 2004). 
A good war with a clear narrative: here was the British understanding of 193945. A struggle that had a dramatic and heroic start, a clear turning point in the middle, and an utterly decisive ending - a war waged for unimpeachable moral reasons. Over the next two decades, this understanding was etched into popular culture through the cavalcade of films about the war produced by British studios.

The total number was remarkable: roughly 1 oo between 1946 and 1965 . In the late 1940 s, some 30 million people went to the cinema every week, at a time when the population of Britain totalled $5^{1}$ million. By 1959 , attendance figures had fallen below 15 million, but this still almost matched the circulation of all national daily newspapers. Many of the movies enjoyed a new lease of life when recycled on television in the 1960 s and 1970 , often reaching much larger audiences. The films were strikingly uniform in their message. Unlike the interwar period, there was no questioning of the validity of the war; nor were soldiers on both sides depicted as essentially ordinary men led as victims to the slaughter. In most movies, the Germans and Japanese were clearly 'baddies', with Nazism treated as essentially a continuation of the Prussian militaristic tradition that had long poisoned Germany. These movies conveyed a largely heroic narrative of the war centred on white British masculinity, featuring stars such as Jack Hawkins and Richard Todd who were tough but reserved, stereotypically English. Apart from occasional Australians, the contribution of the empire to victory did not figure greatly, or that of the Americans (let alone the Russians); nor was there much about the home front and civilians, especially women. Of course, people watched the films mostly for action-packed entertainment-escapes from prisoner-of-war camps being particularly popular. But, at a subliminal level, these films of the $195^{\text {os }}$ and early 1960 s served to reinforce the 1940 saga of Britain Alone locked in heroic combat. 53

During the 1960 , the British did re-discover the Great War but in a very different vein from the grand narrative of 1939-45. The fiftieth anniversary of the conflict between 1964 and 1968 spawned a variety of books and films - most of them highly antagonistic to Haig and the generals and drawing, explicitly or not, on the interwar critiques by Churchill and Lloyd George. The most notorious was The donkeys by Alan Clark - a maverick author on the make who had no scruples about cutting corners. His epigraph was attributed to an exchange between Ludendorff and his chief of staff, in which the latter claimed that 'English soldiers' were 'lions led by donkeys' but Clark later admitted that he had made up the exchange-adapting for his own ends a phrase about

53 Nicholas Pronay, 'The British post-bellum cinema: a survey of the films relating to World War II made in Britain between 1945 and 1960', Historical Journal of Film, Radio and Television, 8 (1988), esp. pp. 39-41; John Ramsden, 'Refocusing “the people's war': British war films of the

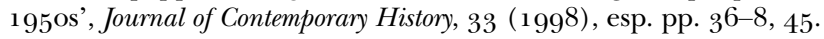


British soldiers from earlier wars. Thanks to him, however, the tag 'lions led by donkeys' has stuck indelibly to the British commanders of the Great War.54

The same themes were picked up in the play Oh what a lovely war (1963), a product of Joan Littlewood's Theatre Workshop in East London, which soon took the West End by storm. This was a bottom-up, lower-class view of the war. The cast, attired as pierrots to suggest the sad clowns who were sent to their deaths, sang soldier songs (one of which became the title) and acted out scenes caricaturing the story of lions led by donkeys: the play was popularly, if wrongly, assumed to be based on Clark's work. Oh what a lovely war moved from lost innocence in Act One to war without end in Act Two. Significantly, it had nothing to say about how and why the war did end in 1918, simply stating on a screen that 'the war to end wars...killed ten million'. The finale became even more poignant in the 1969 cinema version directed by Richard Attenborough, which dissolved into an infinitude of white crosses. The Sunday Telegraph reviewer described the movie as 'the most pacifist statement since All quiet on the Western Front'. This was also the first British film to discuss the causes of the war, dismissing it as a silly family quarrel among the crowned heads of Europe. 55

The continuing lack of a meaningful narrative about the Great War was highlighted by the success of A.J. P. Taylor's The First World War: an illustrated history, published in 1963 a few months after the opening of Oh what a lovely war. This has been described as 'almost certainly the most widely read historical work on the war as a whole in the English language' - selling $25^{\circ}$,ooo copies in its first quarter-century. $5^{6}$ The book's immense impact was due partly to its breezy, ironic tone, often verging on farce (revealingly Taylor dedicated the book to Joan Littlewood). The captions were particularly impish. Sir John French, scurrying through London in top hat and tails, is described as being 'in training for the retreat from Mons', while a photo of the British prime minister, a notorious womanizer, carries the legend 'Lloyd George casts an expert eye over munitions girls.' Taylor's 'palpable lack of deference', observes historian Dan Todman, marked 'a departure from previous historical representations of the war'.57

But Taylor's main achievement was in finally superseding those plodding 1920 s histories of $19^{1} 4^{-1}$. Fifty years on, he finally provided a succinct, readable overview of the whole conflict with a sharp, compelling argument. For Taylor, the First World War was simply a succession of accidents, the product

\footnotetext{
54 Alan Clark, The donkeys (London, 1961), pp. 6, 186; Ion Trewin, Alan Clark: the biography (London, 2009), pp. 181-2, 188-9.

55 Theatre Workshop, Oh what a lovely war, rev. edn by Joan Littlewood (London, 200o), p. 87; Bond, Unquiet Western Front, pp. 63-8, quoting review on p. 67 .

$5^{6}$ Alex Danchev, "Bunking” and "debunking": the controversies of the 1960s', in Bond, ed., The First World War and British military history, p. 263.

57 A.J. P. Taylor, The First World War: an illustrated history (London, 1966 edn), pp. 28, 85; Dan Todman, The Great War: myth and memory (London, 2005), p. 138.
} 
of human error. Contrary to the assumption that great events have great causes, he found it hard to discover any 'profound forces' at work behind the outbreak of the conflict: quite simply 'statesmen miscalculated' in July 1914 . Once mobilization began, the process developed a momentum of its own because of the need to get troops to the right place before it was too late. War, declared Taylor tendentiously, was 'imposed on the statesmen of Europe by railway timetables. It was an unexpected climax to the railway age.' Picking up Alan Clark's epigraph, he claimed that the 'lions led by donkeys' was not merely a British phenomenon: 'all the peoples were in the same boat. The war was beyond the capacity of generals and statesmen alike.' This theme ran right through Taylor's book - from Gallipoli and the shells crisis in 1915 to the equally bumbling German and Allied offensives in 1918. He even asserted that 'there was nothing to choose between the two sides and that the only fault of the Germans was to have lost'.$^{8}$

Taylor reserved his harshest strictures for the first days of the Somme in July 1916. 'Idealism perished on the Somme... The war ceased to have a purpose. It went on for its own sake, as a contest in endurance... The Somme set a picture by which future generations saw the First World War: brave helpless soldiers; blundering obstinate generals; nothing achieved.' Previously, Passchendaele had featured in British memory as the archetype of tragic sacrifice but Taylor helped set up the Somme on its own as the supreme monument to the futility of 1914-18-heightening the contrast with Alamein as the triumphant turning point of Britain's Second World War.59

Equally influential in shaping British views of the Great War in and since the 1960 s were the 'War Poets'. A few of them, notably Siegfried Sassoon and Wilfred Owen, have become trusted interpreters of the war experience - in a way that is unique to Britain. To a significant extent, this was the achievement of war veteran and poet Edmund Blunden. As a person and as a poet, the studiously understated Blunden did not make a huge impact. But 'as critic, editor and academic', the scholar Dominic Hibberd has observed, Blunden 'probably had more influence than anyone on the modern view of $1914^{-1} 8$ verse'. ${ }^{6}$

It was Blunden who first outlined what we might call the poetic narrative of the Great War in a preface entitled 'The soldier poets of 1914-18' to Frederick Brereton's Anthology of war poems (1930). It should be noted that of the 2,225 poets of $1914^{-18}$, less than one fifth saw active service - the rest being civilians - and nearly a quarter of the total were female. But, as the title of Blunden's preface suggests, he chose to privilege the 'soldier poets' above the rest-particularly a few junior officers, often complexed about their

$5^{8}$ Taylor, First World War, pp. 16, 20, 255, 287.

59 Ibid., p. 140. Bond, Unquiet Western Front, p. 63, underplays the importance of Taylor in this shift of attention from Passchendaele to the Somme.

${ }^{60}$ Dominic Hibberd, 'Anthologies of Great War verse: mirrors of change', in Michael Howard, ed., A part of history: aspects of the British experience of the First World War (London, 2009), p. 112. 
masculinity, and mostly from public schools. Five of these young 'soldier poets' were accorded special mention in Blunden's essay, arranged chronologically to create a narrative arc. First came Rupert Brooke, the poet of 'chivalrous obligation', who 'perfected' the patriotic theme of 1914. Then Charles Sorley who, like Brooke, died early but nevertheless 'began to feel the futility of the argument, the doom of the best of men', before his demise at Loos in 1915. By 1916, amid the 'relentless crowding of men into the Golgotha', the war had become 'a recognized error'- an idea captured by Robert Graves. In 191718 , it was Sassoon who mounted 'the attack on war' on 'a large scale' in his collections The old huntsman and Counter-attack. Finally, came Owen, his creativity catalysed by Sassoon, who was 'probably the greatest of the poets that were killed'. And so, said Blunden, amid the horrors of the Somme and Passchendaele, 'in prehistoric 1916 and 1917', there 'arose two poets of unshakable resolution, whose protests will not be surpassed for poetic intensity and plan or for selflessness in fighting this world's battles'. No reference here to 1918 , to the war's end, or to victory because the idea of 'victory' in such a war was devoid of meaning. For Blunden, the task of war poetry was to make 'effectual and eager complaints against the survival of that false gross idol, War'. In his view, the men best fitted for that 'crusade' were those who had fought. ${ }^{61}$

Blunden's short essay in 1930 sketched out a path that the soldier poets of $1914^{-1} 8$ had painfully followed in order to gain their literary victory. And when the fiftieth anniversary of 1914-18 made Great War anthologies fashionable again, Blunden's interpretative framework came into its own. Asked to introduce Brian Gardner's Up the line to death (1964), Blunden reiterated how the poetic voice of 'idealism' in 1914 had turned into 'a cry' by 1917 . Gardner, a popular historian rather than a literary scholar, penned his own Blundenesque introduction, insisting that the 'experiences, and thus many of the emotions, of the poets were no different from those of the rest of the generation' and laying particular emphasis on the first day of the Somme: 'After July, 1916, the poets differed only in that they were more articulate than their comrades. ${ }^{62}$

Gardner's volume was the best known and most durable of the fiftieth-anniversary anthologies but other anthologists were even more didactic. Maurice Hussey, in his collection Poetry of the First World War (1967), asserted that the poems he had chosen, though the product of 'many hands, should be considered as the work of 'one composite writer, the English war poet'. His 'mind', argued Hussey, 'can be seen developing' from a mood of 'patriotic prompting' to 'a more meditative position' and then, in 1916 or 1917 , either to angry

${ }^{61}$ Edmund Blunden, 'The soldier poets of 1914-1918', in Frederick Brereton, ed., An anthology of war poems (London, 1930), pp. 13-24; cf. Catherine Reilly, English poetry of the First World War: a bibliography (London, 1978), p. xix.

${ }^{62}$ Brian Gardner, ed., Up the line to death: the war poets, I9I4-I9I8 (London, 1964), pp. viiviii, xix. 
protest against both the conflict and romantic poetry or else to an acceptance of war as 'the inevitable condition against which the individual's struggle is fruitless'. These fiftieth-anniversary anthologies by Gardner, Hussey, and others were bought in large quantities by schools and then recycled year after year by teachers to justify the original investment. They popularized Blunden's canon of Great War poetry: the verse of junior officers steeped in Romantic literature who moved from patriotic innocence to moral outrage and eventually to a sublime recognition, in Owen's now clichéd words, of 'the pity of War' rather than its glory. ${ }^{6}$

What might be termed the Littlewood-Blunden view of $1914^{-1} 8$ has been hard to dislodge. It is almost as if there are 'Two Western Fronts' - the literary and the historical - each self-contained, with the former still dominating the public imagination. ${ }^{6}$ Some revisionist military historians have mounted a strenuous counter-attack. Gary Sheffield in Forgotten victory (2001) insisted that although the First World War was 'a tragic conflict', it was 'neither futile nor meaningless'. Like the struggles against Napoleon and Hitler, it was 'a war that Britain had to fight and had to win', another round in 'a long struggle to prevent one continental state from dominating the rest'. As for the cliche that the British army were 'lions led by donkeys', Sheffield argued that, 'against a background of revolutionary changes in the nature of war, the British army underwent a bloody learning curve and emerged as a formidable fighting force'. Situating the first day of the Somme within that process as 'an important point' on the 'learning curve', he highlighted the improvement in operational effectiveness, built around a precise and effective creeping barrage, flexible infantry tactics, and all-arms co-operation, which reached its apogee in the last 'Hundred Days' of 1918. Sheffield insisted that in the autumn of 1918, Haig's army - the largest ever deployed in battle by the British Empire achieved 'by far the greatest victory in British military history'. ${ }^{6}$

Sheffield's arguments were echoed by other military historians, for instance William Philpott in his massive study of the Somme, pointedly entitled Bloody victory (2009), which surveyed the five-month battle in its entirety. For Philpott, the attrition of Germany on the Somme was 'the military turningpoint of the war', even though the dénouement came only two years later. This battle was, he argued, the equivalent of Stalingrad in the Second World War, where the appalling human cost has never been allowed to obscure the fact of victory. Why, then, the resistance to his proposition about the comparable place of the Somme in the First World War? Partly because at Stalingrad the Germans were clearly defeated, indeed utterly humiliated, whereas

63 Maurice Hussey, ed., Poetry of the First World War (London, 1967), esp. p. xv; see also http://greatwarfiction.wordpress.com/2010/10/10/up-the-line-to-death/.

64 Bond, Unquiet Western Front, ch. 4 .

65 Gary Sheffield, Forgotten victory: the First World War: myths and realities (London, 2001), pp. xvii, $48,169,253-4,263$. 
nothing so dramatic was evident by time the Somme battle petered out. Also because the dead of 1942-3 were Russians, in 1916 they had been British, from a nation totally unused to attritional war on that scale. The term 'learning curve', borrowed from business psychology, sticks in the gullet of many people in Britain because the curve was so liberally greased with soldiers' blood. What we might call the 'poetic learning curve' traced by Blunden and his emulators has proved much more persuasive.

Sheffield and Philpott hoped to rescue the British army from the mud, both literally and metaphorically. But they had difficulty addressing the fact that the eventual 'victory' was far less clear-cut in 1918 than in 1945. The best Sheffield could claim was that the Great War produced 'negative gains' - in other words stopping something worse from happening, namely German domination of the continent. Yet that argument only served to highlight the need for a second, this time decisive, round in 1939-45. The revisionists may have shifted the terms of debate among specialists but they did not alter British public perceptions of $1914^{-18}$ as recast by the fiftieth-anniversary revisionism in the 1960 . The Great War was no longer just a problem but a tragedy. ${ }^{66}$

\section{V}

In Britain, the First World War remains unsettling - lacking a narrative arc that is clear and compelling, unlike the defined form and resplendent colours of the Second World War. Moreover, as we have seen, the two conflicts are refracted through each other in public memory, heightening the tragic nature of the First when seen in the triumphant light of the Second. Such refractivity is evident in the cultural history of all the belligerent countries, but it takes different forms. Consider briefly the examples of the Soviet Union, the United States, France, and Germany.

The death toll in Russia from the Great War was around two million, comparable in scale to Germany's dead. Yet during the Soviet era (1917 to 1991) no official monuments were erected to commemorate the Great War and its war dead. The communist regime dismissed $1914^{-17}$ as an imperialist conflict, memorable only because it helped trigger the Bolshevik revolution. And for the Russian people two million dead was eclipsed by the nine to fourteen million fatalities over the next five years as a result of the Civil War and its concomitant epidemics and famines. ${ }^{6}$ In contrast to $1914^{-1} 7$, the war of $194^{1-5}$ (in which the USSR suffered 27 million 'premature deaths') became one of the essential political myths of the Soviet state from the 196os. Under Leonid Brezhnev, the regime elevated 'The Great Patriotic War' to cult status. In

${ }^{66}$ Philpott, Bloody victory, pp. 626-9; Sheffield, Forgotten victory, pp. 92-3, 280.

67 Catherine Merridale, Night of stone: death and memory in Russia (London, 200o), pp. 122-9, 452; Melissa Stockdale, 'United in gratitude: honoring soldiers and defining the nation in Russia's Great War', Kritika, 7 (2006), pp. $4^{6} 5^{-8}, 4^{82}$. See more generally Karen Petrone, The Great War in Russian history (Bloomington, IN, 2011 ). 
May 1965 , the twentieth anniversary, Victory Day on 9 May was re-established as a national holiday and major museum displays opened in Moscow and other Hero Cities such as Leningrad and Volgograd (the new name for Stalingrad). Pride in the Great Patriotic War served as the cement of the creaking Soviet system - the tragic good justifying or cloaking necessary evils. Official histories presented Stalin's brutal collectivization and five-year plans as the basis for heroic victory against the fascist aggressor. Many Russians still believe this in the twenty-first century. ${ }^{68}$

In the United States similarly - though for different reasons - the cult status of the Second World War has overshadowed public memory of the First. America was a belligerent against the Kaiserreich for only eighteen months: more US soldiers died from the influenza pandemic of 1918-19 than the 53 , 000 who were killed in combat. ${ }^{69}$ Woodrow Wilson's crusade to 'make the world safe for democracy' soon turned sour with the refusal of the Senate to join his League of Nations, and the country's isolationist mood was accentuated by the shock of the Depression, which many Americans from President Herbert Hoover down blamed on the legacies of the First World War. 'Of the hell broth that is brewing in Europe we have no need to drink', wrote novelist Ernest Hemingway in 1935. 'We were fools to be sucked in once in a European war, and we shall never be sucked in again.' $7^{\circ}$

The Second World War, by contrast, rapidly assumed a sacred place in the nation's social memory, pulling the First with it into a sequential, soaring narrative. This moved from the crusade of 1917-18 and Wilson's tragic failure through the follies of appeasement to a climax in total victory over Hitler and the status of global 'superpower'. Offered a 'Second Chance' the country at last took up its rightful place as global leader. The anguish generated by the Vietnam War served to consecrate $194^{1-5}$ in American public memory as 'the good war' (author Studs Terkel's phrase), while the 'forgotten war' of 1917-18 has remained in its shadow - the only one of the country's twentieth-century conflicts not to have a national memorial on the Mall in Washington. But, in contrast with Russia, the memory of it was essentially positive; and, unlike the British experience, it did not stand in painful, jarring contrast to the heroic narrative about the war against Hitler. ${ }^{71}$

After 1945 , it was the Germans who faced the most demanding challenge in coming to terms with their wartime past. Although the full enormity of the

68 See Nina Tumarkin, The living and the dead: the rise and fall of the cult of World War II in Russia (New York, NY, 1994); Stephen Lovell, The shadow of war: Russia and the USSR, I94 I to the present (Oxford, 2010).

69 See Congressional Research Service, report RL32492, 'American war and military operations casualties: lists and statistics', 26 Feb. 2010, p. 2; and Carol Byerly, 'The US military and the influenza pandemic of 1918-1919', Public Health Reports, 125, no. 3 (2010), pp. 82-91, esp. figure 3 .

$7^{\circ}$ Cushing Strout, The American image of the old world (New York, NY, 1963), p. 205.

$7^{1}$ See generally John Bodnar, The 'good war' in American memory (Baltimore, MD, 2010). 
Holocaust was not yet clear, there was no denying the culpability of Nazi Germany for waging war and perpetrating atrocities. The official line in Konrad Adenauer's Federal Republic was one of 'public penance' but also 'strictly limited liability' - acknowledging the appalling crimes of $1933-45$ but blaming them on a small clique of evildoers, while millions of soldiers and bureaucrats had supposedly been simply obeying orders..$^{2}$

The idea of the Nazi era as a brief aberration from the course of German history-a glitch in the works (Betriebsunfall)73-also helped through the $195^{\text {os }}$ to preserve intact remembrance of $1914^{-18}$ as essentially a good war, waged for national defence especially against Russian barbarism. This position, fundamental to German self-esteem, was eventually undermined in the 196os by Fritz Fischer, a leftist professor at Hamburg, with his book Griff nach der Weltmacht (1961) about Germany's grab for world power in 1914. Fischer and his acolytes sparked a public debate that rumbled on all through the 1960 in seminars, newspapers, and even the television. What became known as the 'Fischer Thesis' suggested that Hitlerite expansionism was no singular aberration but integral to the dynamic of German history since Bismarck and that it was also the responsibility of the whole people rather than just a criminal few - the convenient fiction of the Adenauer era. Reinforced by sixties revelations about Auschwitz and Nazi war crimes, it established a version of 191418 that still holds sway in Germany, even though partially dented by recent historians (mainly non-German) who place primary responsibility for 1914 on the Serbs and the Russians. 74

In France, as well, the two world wars became central to public debate during the 1960 , but in different ways from West Germany. The French had ended up on the winning side in 1945 but the country's humiliating defeat in 1940 and the complicity of the Vichy regime with the Third Reich posed huge moral problems. When Churchill's memoirs appeared in French, his Paris publishers faithfully translated all the titles of his six volumes except for one: volume II about 1940, entitled Their finest hour, became L'heure tragique. With 80o,ooo anciens combattants of 1914-18 still alive in 1948, the French found it easier and more comforting in the $195^{\text {os }}$ to commemorate the tragic but heroic sacrifice of 1.3 million in la grande guerre to defend and cleanse la patrie rather than to talk about les années sombres - the dark years of 1940-4.

It was Charles de Gaulle, leader of the Free French in London during the war and president of the new Fifth Republic from $195^{8}$ to 1969 , who constructed

$7^{2}$ Mary Fulbrook, German national identity after the Holocaust (Cambridge, 1999), pp. 59-6o, 66; cf. Friedrich Meinecke, A German catastrophe, trans. Sidney B. Fay (Boston, MA, 1950), p. 96.

73 In origin, a mocking caricature by Munich historian Helmut Krausnick - see Astrid Eckert, 'The transnational beginnings of West German Zeitgeschichte in the 1950s', Central European History, 4o (2007), p. 86.

74 'The Fischer controversy $5^{\circ}$ years on' - special issue of the Journal of Contemporary History, 48 (2013), pp. 231-417; cf. Christopher Clark, The sleepwalkers: how Europe went to war in I9I4 (London, 2012); Sean McMeekin, July I9I4: countdown to war (London, 2013). 
the dominant French narrative of 1939-45. In his war memoirs written during the $195^{\circ}$ and in his actions as head of state, de Gaulle presented a distinctive version of history with himself as the embodiment of the national will and as the defender of France against not only the German foe but also against the malignant communists in the Resistance and against British and American allies who sought to 'vassalize' the country. In the words of Culture Minister André Malraux, 'the Resistance equals de Gaulle; de Gaulle equals France; hence the Resistance equals France'.75

For a while, the Gaullian version of history held sway but, in the 1970 , what has been called 'the glacier of official memory' in France began to crack. $7^{6}$ Marcel Ophuls's film Le chagrin et la pitié ( 1969) contested most of the national myths about the war. This was a four-hour account of daily life in the town of Clermont-Ferrand under German occupation, built around extended interviews, which suggested that many citizens collaborated or sat on the fence and also hinted at the extent of French anti-Semitism. The sorrow and the pity - seen or heard of - opened up the debate on Vichy's complicity in the deportation of the Jews and underlined the extent to which the Second World War had been a civil war in France. 77

And so, by the late 1960 , in West Germany both world wars had become profoundly negative; in France, despite the Gaullian narrative, the dark shadows of the Second tended to obscure the continuing lustre of the First. All very different from the situation in Britain where the Second World War, in contrast with the First, was seen as a heroic triumph. But France and West Germany found a way to dig themselves out of the entrenched narrative of two world wars through a process that was denied to Britain, or more exactly that the British denied to themselves. This was European integration built around the European Coal and Steel Community (1952) and the European Economic Community (1958).

As the French socialist and Resistance leader Christian Pineau observed, a couple of years in a Gestapo cell and Buchenwald concentration camp could inspire either a passion for revenge on Germany or a determination that there would be no more camps. $7^{8}$ Vengeance had fuelled the Thirty Years War: for France in 1914, the recovery of Alsace and Lorraine, lost in 1870; for Germany in the 1930s, the annulment of the Diktat of Versailles and the achievement of 'living space' in Europe. Although no formal peace conference was held after 1945 because of the Cold War, the Treaty of Rome, which Pineau signed for France in 1957, was effectively a peace settlement for Western Europe. The idea of France and West Germany as founders of the EEC

75 Quoted in Henry Rousso, The Vichy syndrome: history and memory in France since 1944, trans. Arthur Goldhammer (Cambridge, MA, 1991), p. 90.

$7^{6}$ Julian Jackson, France: the dark years, I940-1944 (Oxford, 2001), p. 613.

77 Rousso, Vichy syndrome, pp. 110-11.

$7^{8}$ Olivier Wieviorka, La mémoire désunie: le souvenir politique des années sombres de la libération à nos jours (Paris, 2010), pp. 134-5. 
would have seemed totally incredible a decade before. 'The era of wars by West European people against one another has finally come to an end', Adenauer proclaimed in delight. He forged a close rapport with the French president, somewhat against expectations since de Gaulle had spent half of the Great War in German prisoner-of-war camps while Adenauer's first visit to Paris had been just before the German delegation signed the Treaty of Versailles. In an intensely symbolic moment in July 1962, the two leaders took mass together at the High Altar in Reims Cathedral-sacred coronation place of French kings but also site of one of Germany's most notorious cultural 'atrocities' of 1914. The Franco-German treaty that de Gaulle and Adenauer signed in January 1963 in the Elysée Palace featured grass-roots co-operation, such as town-twinning, youth exchanges, and language-learning to help create a new generation that was less nationalistic. 79

And so, despite the difficulties that France and West Germany each faced in coming to terms with the past, they were now clearly moving on. European integration promised a new and more hopeful future, transcending the animosities of two world wars. It was also welcomed by their smaller neighbours Belgium, Luxembourg, and the Netherlands-who had formed their own customs union (Benelux) in 1948. The first two countries had tried to remain neutral in both wars but to no avail; the Dutch managed to keep out of the Great War but neutrality got them nowhere in 1940. In short, all three countries knew from painful experience their geopolitical place, trapped in the jaws of the Franco-German antagonism; so in the $195^{\mathrm{os}}$, they championed European integration in the hope of drawing the teeth of their bellicose neighbours. Italy, too, was keen, seeing this as a way to transcend its post-war pariah status. Across the Channel, however, British governments of the $195^{\mathrm{os}}$, both Labour and Conservative, were taken aback by the speed and intensity of European integration. They stood aloof from the ECSC and EEC, convinced that Britain's economic interests lay in its global trading networks with the United States and the Commonwealth rather than a tight, protectionist continental bloc. Indeed, there was an underlying doubt that the 'Europeans' would really get their act together, given the ruinous history of the last half-century. But France, West Germany, and Benelux had learnt a painful lesson: their mantra was, in effect, 'if you can't beat them, join them'. The British attitude, by contrast, was: 'We did beat them, so we don't need to join them.'

Allusions to Britain's war experience are evident in Whitehall documents of the time about 'Europe'. In November 1944, Churchill derided Foreign Office talk about a possible post-war Western European bloc in language that bore the marks of 1940:

Until a really strong French army is again in being, which may well be more than five years away or even ten, there is nothing in these countries but hopeless weakness.

79 Hans-Peter Schwarz, Adenauer: Der Staatsmann, I952-1967 (Munich, 1994), p. 297. 
The Belgians are extremely weak, and their behaviour before the War was shocking. The Dutch were entirely selfish and fought only when they were attacked, and then for a few hours. Denmark is helpless and defenceless, and Norway practically so. That England should undertake to defend these countries, together with any help they may afford, before the French have the second Army in Europe, seems to me contrary to all wisdom and even common prudence. It may well be that the Continent will be able to fire at us and we at the Continent, and that our island position is damaged to that extent. But with a strong Air Force and adequate naval power, the Channel is a tremendous obstacle to invasion by Armies and tanks. ${ }^{80}$

After the war, the looming threat of nuclear weapons diminished Churchill's sense of security and he also championed a new Franco-German entente within what he liked to call a 'United States of Europe'. But his underlying position, though left deliberately vague, was that the British would be among the 'friends and sponsors of the new Europe', rather than an integral part of it, because of their special ties with the Commonwealth and the United States. He developed the geopolitical image of the 'Three Circles' - the 'British Commonwealth and Empire', the 'English-speaking world' including the USA, and what he termed 'United Europe'. Reflecting in 1948 on these 'three inter-linked circles', he said 'you will see that we are the only country which has a great part in every one of them. We stand, in fact, at the very point of junction' and 'have the opportunity of joining them all together'. Here was a conception of British interests and identity that included Europe but was in no way exclusively European. ${ }^{81}$

This emphasis was not peculiar to Churchill. An interdepartmental meeting of top-level civil servants in January 1949 to discuss attitudes to 'European cooperation'-involving representatives of the Treasury, Foreign Office, Dominions Office, and Board of Trade - concluded that Britain had 'a major interest in European recovery', both for economic stability and the containment of communism, but had no interest in 'long-term co-operation' with continental Europe.

Our policy should be to assist Europe to recover as far as we can...But the concept must be one of limited liability. In no circumstances must we assist them beyond the point at which the assistance leaves us too weak to be a worth-while ally for U.S. A. if Europe collapses. ${ }^{82}$

8o Prime minister to foreign secretary, 25 Nov. 1944, TNA, prime minister's files, PREM 4 / 3o/8, fo. 488. Churchill's comment on Belgium is presumably a reference to the country's decision to abrogate its French alliance and opt for neutrality in 1936 .

${ }^{81}$ Quotations from his speeches at Zurich, 19 Sept. 1946, and Llandudno, 9 Oct. 1948, in Robert Rhodes James, ed., Winston S. Churchill: his complete speeches, I874-1963 (8 vols., New York, NY, 1974), vII, pp. $73^{81}$ and 7712.

82 'Policy towards Europe', agreed minute of meeting on 5 Jan. 1949, printed in Richard Clarke, Anglo-American economic collaboration in war and peace, I942-I949 (Oxford, 1982), pp. $208-9$. 
In other words, there had to be an exit strategy, a Dunkirk scenario. This warinduced wariness about the continent was expressed more emotionally by Ernest Bevin, the Labour foreign secretary, when challenged about European co-operation by American officials in August 1950. Britain was 'not a part of Europe', he exclaimed, 'not simply a Luxembourg'. According to the Foreign Office record of the meeting, Bevin explained that

The people in this country were pinning their faith on a policy of defence built on a Commonwealth-U.S. A. basis - an English-speaking basis. People here were frankly doubtful of Europe. How could he go down to his constituency - Woolwich which had been bombed by Germans in the war, and tell his constituents that Germans would help them in a war against Russia?... Similarly in regard to France, the man in the street, coming back from holiday there, was almost invariably struck by the defeatist attitude of the French.

Bevin's attempts at popular psychology should be taken with a pinch of salt - being himself a devotee of Hove rather than Le Touquet-but one catches here a resonant echo of $1940 .{ }^{83}$

However, once the Six was up and running in the late $195^{\mathrm{OS}}$ - incredible as this seemed - attitudes in London changed fast. There was now a real danger of Britain being marginalized in global affairs. Aside from 'the economic damage which we will suffer from the consolidation of the Six', a Whitehall committee warned in 1960 , 'if we try to remain aloof from them...we shall run the risk of losing political influence and of ceasing to be able to exercise any claim to be a world Power'. ${ }^{4}$ Two considerations gave weight to these fears. First, the British Empire was contracting suddenly and sharply. Seventeen British colonies gained their independence in 1960-4, compared with only three in the period 1948-6o. Second, the United States warmly backed the process of integration, welcoming this sign that the ever-feuding Europeans were finally burying the hatchet. Britain could not afford to remain outside Europe's new magic circle if it wanted to retain credibility in Washington. When former US Secretary of State Dean Acheson declared in 1962 that 'Great Britain has lost an Empire and has not yet found a role', he struck a very raw nerve in London. Prime Minister Harold Macmillan issued a lofty rebuke, claiming that Acheson had 'fallen into an error which has been made by quite a lot of people in the course of the last four hundred years', from Philip II of Spain and Napoleon to the Kaiser and Hitler. But a heroic saga of past victories culminating in 'our finest hour' cut little ice in the New Europe and the post-colonial world.$^{85}$

\footnotetext{
83 Memo by Pierson Dixon, 23 Aug. 195o, TNA, Foreign Office papers, FO 80o/517, US/ $5 \mathrm{o} / 35$.

${ }_{4}$ Quoted in N. Piers Ludlow, Dealing with Britain: the six and the first UK application to the EEC (Cambridge, 1997), p. $3^{2 .}$

85 David Reynolds, Britannia overruled: British policy and world power in the twentieth century (2nd edn, London, 2000), pp. 208, 212 ; Harold Macmillan, At the end of the day, 1961-1963 (London, 1973), p. 339 .
} 
Acheson's warning about losing an empire and not finding a role hit home in 1963 and again in 1967 , when de Gaulle twice vetoed Britain's application to join the EEC on the grounds that the country was not truly 'European' and would act as a 'Trojan horse' for American influence. The French president still smarted at his position of inferiority when exiled in Britain between 1940 and 1944. He had not forgotten Churchill's warning on the eve of D-Day that the transatlantic alliance would always be Britain's first principle of foreign policy. The dramatic events of 1940 had indeed proved a great divide between Britain and France and, more generally, Britain and the continent. By the time de Gaulle's successor, Georges Pompidou, relented and Tory Prime Minister Edward Heath was able to take Britain into the EEC in January 1973, the Community had been in operation for fifteen years and the original deal-making among the Six had set firm. This required Britain to accept arrangements that did not really fit its economic interests, particularly the Common Agricultural Policy (CAP), which suited France's large and inefficient agricultural sector, and the mechanisms for calculating the budget, which penalized a high-importing country like Britain. Heath hoped that, once inside, he could change the budget arrangements, expand the regional funds to Britain's benefit, and thereby gradually reduce the dominance of the CAP. But 1973 was also the year of the oil crisis and the onset of stagflation. The EEC had been launched during the era of post-war prosperity; Britain joined just as the boom ended and the recession began, drastically reducing Heath's room for manoeuvre.

In any case, 1973 did not prove a decisive moment for Britain because there was no clear, bipartisan national consensus in favour of 'Europe'. Initially, the issue was especially divisive for the Labour party. Heath's successor, Harold Wilson, contrived a cosmetic 'renegotiation' of Britain's terms of entry and then put it to the country in a referendum, securing a two-third majority of those voting in June 1975. In the 1980s, Margaret Thatcher waged a protracted struggle with 'Brussels' over the scale of Britain's budget rebate and the EC's drive to closer integration, both financial and political. Her successor, John Major, secured a British opt-out from key clauses of the Maastricht Treaty in 1992, including its commitment to monetary union - but this did not save him from relentless criticism by those he called the 'bastards' on the Tory right. And in 2015, another Conservative premier, David Cameron - under pressure from the new UK Independence party (UKIP) and from Tory 'Eurosceptics' - repeated Wilson's party trick of forty years before. He found substantive 'renegotiation' even harder given the size of the twenty-firstcentury European Union but he used the (again) largely cosmetic changes he secured to go to the country with an 'In or Out?' referendum on 23 June 2016. After a bitter struggle, full of hyperbole and abuse from both sides, which split the Tory party and the country, the vote for 'Leave' was $5^{2}$ per cent to 48 per cent. Tellingly, Leave's opponents campaigned under the tepid slogan 'Remain' rather than championing 'Europe'. 
In 1990, the political scientist Stephen George described Britain as the perpetual 'Awkward Partner' in the European Community - a late entrant and then uneasy member, at odds with the supranational ethos and institution-building of the European project. At the time, George's argument was contested by various scholars. Hadn't other countries played the 'European' game for national ends, including France and Germany? Did the 'awkwardness' thesis assume a 'Whiggish' story of progressive European integration that was not historical 'fact' but simply the official dogma of the European Commission? ${ }^{86}$ Although these criticisms had some validity, in 2016 George's argument was categorically vindicated. Britain's path was unique. No other state joined the EC/ EU, then held two referenda in forty years about whether to get out, and eventually decided to do so.

This article has concluded by suggesting that Britain's evident discomfort with 'Europe' is connected with its divergent experience and narratives of the two world wars compared with those of its continental West European neighbours. The conflict of 1914-18 proved deeply unsettling for the British because of its human cost and inconclusive outcome. It could only be justified and made meaningful if the Great War proved to be 'the war to end war'. That hope, underpinning 'appeasement' in the 1930s, went up in smoke in 1939. The second war generated a much more satisfactory narrative, at once heroic and moral, with a plausible beginning, middle, and end. 'Our Finest Hour', Alamein, Unconditional Surrender, and the Death Camps are landmarks along the now familiar British road to 1945 . Unlike 1914-18, over which the 'battle of the books' still rumbles on, 1939-45 brought forth a supreme narrator in the form of Winston Churchill whose perspective, although contested now by scholars, has become integral to public discourse and political culture. The elevation of the Second World War in British public life, reinforced

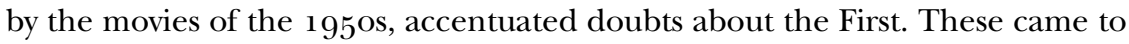
the surface in the 196os, at the time of the fiftieth anniversary when books, movies, and the cult of the 'war poet' combined in a 'bottom-up', soldierseye-view of the war as pointless human tragedy. This is the perspective still dominant among the British public today despite the efforts of revisionist military historians.

A narrative of tragedy, followed by a narrative of triumph. Yet, for all the differences between the story-lines, in both world wars Britain was a semi-detached participant - fighting on foreign soil, across the Channel, and across the oceans.

86 Stephen George, An awkward partner: Britain in the European community (Oxford 1990); cf. Jim Buller, 'Britain as an awkward partner: reassessing Britain's relations with the EU', Politics, 15 (1995), pp. 33-42; Mark Gilbert, 'Narrating the process: questioning the progressive story of European integration', Journal of Common Market Studies, 46 (2008), pp. 641-62. 
The First World War was not evidently a war of self-defence: it was waged 'over there' for the values of liberty and civilization. The Second World War was more obviously about national survival, especially in 1940, but the struggle was won in a way that enhanced Britain's sense of distance from the continent that it helped to redeem: the country's closest allies were the 'English-speaking Peoples' of America and the Commonwealth. The emotional commitment of the continent to European integration reflects a war experience fundamentally at odds with that of Britain. It is significant that "when the German and French media use the term "Europe" they mean "us"; when the British media use the term, they usually mean "them"., 87

The tragic narrative of $1914^{-1} 8$ and the triumphalist narrative of $1939^{-45}$ also share a sense of Britain as author of its fate-choosing whether or not to enter conflicts, determining its own destiny as a maker of history. The second half of the twentieth century, with the sudden end of empire and reluctant slide into 'Europe', seems, by contrast, a story of Britain as a victim of history without a positive European metanarrative to serve as a cushion for decline and a springboard for the future, as it does in the case of France and Germany. The Brexit vote in 2016 was in part an attempt to reassert the self-image of Britain as maker not victim of history. In that process, the Churchillian moment - 1940 as the country's 'finest hour' - continues to exert magnetic appeal. Yet the deeper implication of that phrase is sobering. The superlative, 'finest', implies that things can never be as fine again: hardly an empowering conception of the past with which to face the future. Having lost an empire, the British are now losing 'Europe'; they may even be losing the United Kingdom itself. Twentyfirst-century Britain is a country in search of its grand narrative. That, one might say, is the British problem.

${ }^{87}$ Smith, Britain and 1940 , p. 148. 